\title{
Enhancement of stripping technique for Copper(II) detection in water sample using N,N'-bis(2-hydroxy-4-methoxyacetophenone)ethylenediamine (BME)
}

\author{
Syaza Azhari, Rahmalan Ahamad* and Farediah Ahmad \\ Department of Chemistry, Faculty of Science, UTM, 81310 UTM Skudai, Johor, Malaysia, \\ *Corresponding Author: rahmalan@utm.my(R.Ahamad)
}

\section{Article history :}

Received 22 February 2014

Revised 11 March 2014

Accepted 20 July 2014

Available online 7 August 2014

\section{GRAPHICAL ABSTRACT}

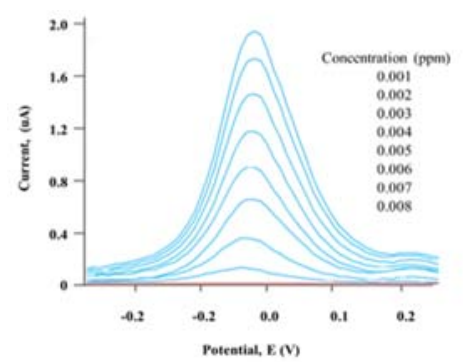

\section{ABSTRACT}

A highly sensitive, rapid, simple and selective stripping assay for the determination of trace copper(II) is proposed. The selectivity and sensitivity of the electroanalytical process on a glassy carbon (GC) electrode were enhanced using the newly synthesized Schiff base N,N'-bis(2-hydroxy-4methoxyacetophenone)ethylenediamine (BME). The methodology is based on the accumulation of copper(II)-BME complex onto the GC electrode, followed by electrochemical oxidation of the adsorbed species. The effect of experimental parameters such as $\mathrm{pH}$, BME concentration, scan rate, accumulation time and accumulation potential on the sensitivity of copper(II) detection were investigated. Under the optimal conditions, BME has successfully enhanced the copper(II) detection using the GC electrode by nearly $95 \%$ with detection limit (LOD) of $2.6 \mathrm{ngL}^{-1}$. The effects of interfering ions such as $\mathrm{Cd}(\mathrm{II}), \mathrm{Zn}(\mathrm{II})$, $\mathrm{Fe}(\mathrm{II}), \mathrm{Cr}(\mathrm{III})$ and $\mathrm{Pb}(\mathrm{II})$ were also investigated. The applicability of this technique was illustrated by the determination of copper(II) ion in tap water.

Keywords: Copper(II), N,N'-bis(2-hydroxy-4-methoxyacetophenone)ethylenediamine, glassy carbon, stripping

\section{INTRODUCTION}

Concern over toxicity effects in the environment has been the main motivation for continuous improvement of copper ion $(\mathrm{Cu}(\mathrm{II}))$ determination in water samples. Copper is an essential element that plays an important role in human body functions such as haemoglobin synthesis, connective tissue development, normal function of the central nervous system and oxidative phosphorylation [1]. However excessive intake of copper may lead to accumulation of the metal ion in vital organs such as liver, in particular. There is a high probability of copper ion to enter the food chain due to widespread use in water pipes, animal feed, vegetables and grains spray to prevent fungus and algae growth [2]. Therefore it is essential to closely monitor the $\mathrm{Cu}$ (II) concentration in the environment.

Effective monitoring of $\mathrm{Cu}$ (II) in the environment involve the use of sophisticated and sensitive analytical techniques including Uv-Visible spectrophotometry, inductively coupled plasma mass spectrometry (ICP-MS) $[3,4]$, inductively coupled plasma optical emission spectrometry (ICP-OES), atomic absorption spectrophotometry (AAS) [5, 6] and atomic fluorescence spectrometry (AFS) [7]. However, most of these techniques have limitation one way or another in terms of detection limits, time consuming, capital and operational costs, the need for specialized expertise and sample pretreatment steps.

On the other hand, electrochemical methods such as stripping voltammetry (SV) present an effective, low cost and simple technique for the determination of $\mathrm{Cu}$ (II) in water samples [8]. SV involves in-situ preconcentration of the analyte that proceeds by electrodeposition on the electrode surface $[9,10]$. SV at hanging mercury electrode (HMDE) has been reported for the determination of $\mathrm{Cu}$ (II) where good results were obtained with enhanced selectivity

and sensitivity in water samples [11-16]. Concern over the toxicity effect renders unfavourable use of mercury as the electrode material which motivates the development of alternative electrodes in voltammetry. Carbonaceous materials present most popular choice due to high electron transfer rate and broad anodic potential window.

During the past two decades, considerable attention has been paid to the chemistry of Schiff Base ligands that contain nitrogen and other donors due to the unique properties for metal complexation [17]. This may be attributed to their stability and potential applications in many fields, such as electrocatalysis [18], molecular materials having nonlinear optical (NLO) properties [19], 
and pharmaceutical applications [20]. Schiff Bases have the capability to promote electron transfer reaction and improve sensitivity in electrochemistry, and thus they are widely used to prepare modified electrodes. Most of the applications of Schiff Base in electrochemistry reported involve carbon paste electrode modification [21-23] and carrier in ion selective membrane [24-26]. Moreover, there is an opportunity to enhance the electrochemical detection of metal ions by utilizing novel Schiff base modified electrode.

The main objective of the present study is to develop a new selective, highly sensitive and environmentally friendly voltammetry technique for the determination of metal ions. To the best of our knowledge, no report was found on the use of Schiff base modified glassy carbon (GC) electrode for the determination of $\mathrm{Cu}(\mathrm{II})$ ions. Thus in this paper, the synthesis and characterization of a new Schiff base compound and its application to enhance $\mathrm{Cu}$ (II) ions detection by glassy carbon electrode.

\section{EXPERIMENTAL}

\subsection{Chemicals and reagents}

The chemicals used for the synthesis of ligands were, 2,4-dihydroxyacetophenone (Fluka) and ethylenediamine (Merck). Britton Robinson buffer ( $\mathrm{pH} 2-$ 11) were prepared by mixing appropriate amount of boric acid $\left(\mathrm{H}_{3} \mathrm{BO}_{3}\right)$, glacial acetic acid $\left(\mathrm{CH}_{3} \mathrm{COOH}\right)$ and $85 \%$ orthophosphoric acid $\left(\mathrm{H}_{3} \mathrm{PO}_{4}\right)$ in deionized water in 1000 $\mathrm{mL}$ volumetric flask to be used as supporting electrolyte. Desired standard solutions $\mathrm{Cu}(\mathrm{II})$ were prepared by dissolving the sulphate $\left(\mathrm{CuSO}_{4} .5 \mathrm{H}_{2} \mathrm{O}\right)$ in distilled water in $100 \mathrm{~mL}$ volumetric flask. A stock solutions of ligand were prepared by dissolving appropriate amount of ligand in dimethylformamide (DMF). The de-ionized water used throughout the present work was obtained from Barnstead Ultra Nanopure water system.

\subsection{Instrument}

The $0.2 \mathrm{~mm}$ Merck pre-coated silica gel plates thinlayer chromatography (TLC) was used to monitor the Schiff base synthesis and visualized with UV light. The ${ }^{1} \mathrm{H}$ and ${ }^{13} \mathrm{C}$ NMR spectra (400 and $100 \mathrm{MHz}$ respectively) were recorded on a Bruker Avance 400 using deuterated chloroform $\left(\mathrm{CDCl}_{3}\right)$, dimethylsulfoxide (DMSO) and methanol $\left(\mathrm{CD}_{3} \mathrm{OD}\right)$ as the solvent. The infrared (IR) spectra were measured on a Shimadzu 8000 or PerkinElmer series 1600 spectrometers as thin film $(\mathrm{NaCl}$ windows) for liquid samples or $\mathrm{KBr}$ pellet for solid samples. Melting points were measured on a Leica Galen III micro melting point apparatus and were not corrected. All electrochemical measurements were performed using EA163 potentiostat. A conventional three electrode cell configuration was used for the voltammetric measurements. A glassy carbon was used as the working electrode, silver-silver chloride $(\mathrm{Ag} / \mathrm{AgCl})$ as the reference electrode and platinum wire as the auxiliary electrode.

\subsection{Synthesis of Schiff Base}

$N, N$ '-bis(2-hydroxy-4-methoxyacetophenone) ethylenediamine (BME) was prepared as follows: 2,4dihydroxyacetophenone $(1.5 \mathrm{~g}, 9.9 \mathrm{mmol})$, methyl iodide (3.16 g, $22.3 \mathrm{mmol})$ and anhydrous potassium carbonate $(8$ g) in dry acetone was refluxed for $4 \frac{1}{2}$ hour. The reaction was monitored by TLC. The mixture was evaporated off by using rotary evaporator and filtered by vacuum filtration. The residue was purified by column chromatography (Hexane: Diethyl Ether, 98:6) to give 2hydroxy-4-methoxyacetophenone as a yellow oil $(976 \mathrm{mg}$, 81\%); IR $v_{\max }(\mathrm{KBr}) \mathrm{cm}^{-1}: 3437(\mathrm{O}-\mathrm{H}), 2950\left(\mathrm{sp}^{3}-\mathrm{C}-\mathrm{H}\right)$ and $1626(\mathrm{C}=\mathrm{O}), 1259(\mathrm{C}-\mathrm{O}) ;{ }^{1} \mathrm{H}$ NMR (acetone-D): 12.77 $(1 \mathrm{H}, \mathrm{s}, 2-\mathrm{OH}), 7.80(1 \mathrm{H}, \mathrm{d}, J=8.8 \mathrm{~Hz}, \mathrm{H}-7), 6.49(1 \mathrm{H}, \mathrm{dd}$, $J=2.4$ and $8.8 \mathrm{~Hz}, \mathrm{H}-6), 6.40(1 \mathrm{H}, \mathrm{d}, J=2.4 \mathrm{~Hz}, \mathrm{H}-3), 3.86$ $\left(3 \mathrm{H}, \mathrm{s}, 5-\mathrm{OCH}_{3}\right)$ and $2.56(3 \mathrm{H}, \mathrm{s}, \mathrm{H}-9)$. 2-hydroxy-4methoxyacetophenone was added dropwise to ethylenediamine solution $(1 \mathrm{mmol})$ in dry ethanol $(10 \mathrm{~mL})$. The mixture was then refluxed for 24 hours. The mixture was evaporated using rotary evaporator and cooled at room temperature, separated by vacuum filtration and washed with cooled ethanol. Yielded as yellow crystals $(301 \mathrm{mg}$, $69 \%$ ) with melting point $240^{\circ} \mathrm{C}-242^{\circ} \mathrm{C}$; IR $\mathrm{V}_{\max }(\mathrm{KBr}) \mathrm{cm}^{-}$ 1: $3435(\mathrm{O}-\mathrm{H}), 2923\left(\mathrm{sp}^{3} \mathrm{C}-\mathrm{H}\right), 1595(\mathrm{C}=\mathrm{N}) ;{ }^{1} \mathrm{H}$ NMR $\left(\mathrm{CDCl}_{3}\right): 7.38\left(2 \mathrm{H}, \mathrm{d}, J=8.8 \mathrm{~Hz}, \mathrm{H}-8 / \mathrm{H}-8^{\prime}\right), 6.38(2 \mathrm{H}, \mathrm{d}$, $J=2.40 \mathrm{~Hz}, \mathrm{H}-4 / \mathrm{H}-4$ '), $6.31(2 \mathrm{H}, \mathrm{dd}, J=2.4$ and $8.8 \mathrm{~Hz}, \mathrm{H}-$ 7/H-7'), 3.94 (4H, s, H-10/H-10'), 3.81 (6H, s, 6-OCH3/6$\left.\mathrm{OCH}_{3}{ }^{\prime}\right)$ and $2.36\left(6 \mathrm{H}, \mathrm{s}, \mathrm{H}-9 / \mathrm{H}-9{ }^{\prime}\right) ;{ }^{13} \mathrm{C} \mathrm{NMR}\left(\mathrm{CDCl}_{3}\right)$ : 172.25 (C-1/C-1'), 168.56 (C-3/C-3'), 163.85 (C-2/C-2'), 129.61 (C-8/C-8'), 112.41 (C-5/C-5'), 105.69 (C-4/C-4'), 102.01 (C-7/C-7'), 55.23 (C-6/C-6'), 48.44 (C-10/C-10') and 14.50 (C-9/C-9').

\subsection{Electrochemical procedure}

The surface of the GC electrode was polished with $1.0 \mu \mathrm{m}$ alumina water slurry using a polishing cloth. The electrode was rinsed and then sonicated in distilled water followed by methanol for 10 mins respectively. A $15 \mathrm{ml}$ BRB solution was placed in the voltammetric cell and the required amount of $\mathrm{Cu}(\mathrm{II})$ ions and $100 \mu \mathrm{L}$ of $0.001 \mathrm{M}$ of $\mathrm{BME}$ dissolved in DMF were introduced into the voltammetric cell. A potential was set to $-1.0 \mathrm{mV}$ vs $\mathrm{Ag} / \mathrm{AgCl}(3 \mathrm{M})$, whereas the accumulation time was set to 60 s. Typically. the DPASV voltammetric parameters were as follows: pulse amplitude $25 \mathrm{mV}$, scan rate $10 \mathrm{mV} / \mathrm{s}$. Prior to the voltammetric measurement pure nitrogen were purge into the solution while maintain the stirrer at 400 rpm. Voltammograms were then recorded by scanning anodically from $-0.2 \mathrm{mV}$ vs $\mathrm{Ag} / \mathrm{AgCl}$ to $+0.4 \mathrm{mV}$ vs $\mathrm{Ag} / \mathrm{AgCl}$. All the data were obtained at room temperature.

\section{RESULTS \& DISCUSSION}




\subsection{Spectral properties-Schiff Base BMEs}

The methylation of 2,4-dihydroxyacetophenone occurred via Williamson synthesis of the phenoxide ion and methyl iodide. Potassium carbonate was used in this reaction as base to abstract a proton from hydroxyl group at the para position to form the phenoxide ion. Following the SN2 rule, the nucleophilic phenoxide ion attacks the back side of the electrophilic carbon atom of the methyl iodide to form 2-hydroxy-4-metoxyacetophenone and releases the iodide ion. The 2-Hydroxy-4-metoxyacetophenone was isolated as a yellow oil in $81 \%$ yield. The N,N'-bis(2-hydroxy-4-methoxyacetophenone)ethylenediamine (BME) was obtained as a yellow crystal in $69 \%$ yield with melting point $240^{\circ} \mathrm{C}-242^{\circ} \mathrm{C}$ through the condensation reaction between 2-hydroxy-4metoxyacetophenone and ethylenediamine.

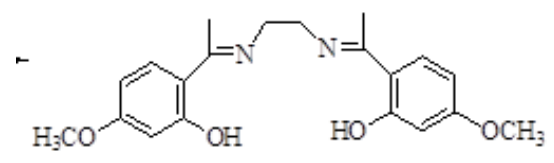

Fig. 1 Structure of BME

The IR spectrum of the BME has several prominent bands appearing at about $3435 \mathrm{~cm}^{-1}$ and $1595 \mathrm{~cm}^{-1}$ due to $\mathrm{O}-\mathrm{H}$ and $\mathrm{C}=\mathrm{N}$ stretching modes, respectively. The NMR spectra of the BME have been recorded in DMSO-d6. The ${ }^{1} \mathrm{H}$ NMR of BME shows tri-substituted patterns for aromatic protons resonance at $7.38(2 \mathrm{H}, \mathrm{d}, \mathrm{J}=8.8 \mathrm{~Hz}), 6.38$ $(2 \mathrm{H}, \mathrm{d}, \mathrm{J}=2.40 \mathrm{~Hz})$ and $6.31(2 \mathrm{H}, \mathrm{dd}, \mathrm{J}=2.4$ and $8.8 \mathrm{~Hz})$ corresponding to $\mathrm{H}-8 / \mathrm{H}-8$, , H- $4 / \mathrm{H}-4$ ' and $\mathrm{H}-7 / \mathrm{H}-7$ ' respectively. The methoxyl groups of $\mathrm{H}-6 / \mathrm{H}-6$ ' were represented by a singlet at $\delta 3.81$. The other singlet appeared at $\delta 2.36$ was assigned to two methyl groups of H-9/H-9'. The presence of methylene protons $\mathrm{H}-10 / \mathrm{H}-10$ ' were represented by the singlet at $\delta 3.94$. The formation of Schiff base BME was further confirmed by the 13C NMR spectrum. The presence of eight quaternary carbon represented by the signals resonated at $\delta 172.25(\mathrm{C}-1 / \mathrm{C}-$ 1 '), $\delta$ 168.56, (C-3/C-3'), $\delta$ 163.85(C-2/ C-2') and $\delta$ 112.41 (C-5/C-5'). The aromatics carbon of C-4/C-4', C-7/ C-7' and C-8/C-8' were displayed at $\delta 105.69, \delta 102.01$ and $\delta 129.61$. The signals at $\delta 14.50$ and $\delta 48.44$ attributed to methylene and methyl carbons were observed for C-9/C9' and C-10/C-10' respectively.

\subsection{Cyclic voltammetry characterization of Schiff- Base Ligands}

The cyclic vltammograms at $250 \mathrm{mV} / \mathrm{s}$ of $\mathrm{N}, \mathrm{N}$ 'bis(2-hydroxy-4-methoxyacetophenone)ethylenediamine (BME) consists of a single anodic peak at potential range from +0.6 to $+1.2 \mathrm{~V}$ as shown in Fig 2. No cathodic wave occurs in the reverse scan which indicates that the oxidation process is irreversible. This could be attributed to the slow electron transfer kinetics or formation of electro-inactive species of the oxidation products.

As shown in Fig 3, the peak currents of the oxidation initially decreased with increasing number of potential cycles and become constant after approximately $20^{\text {th }}$ cycle. The gradual decrease of the peak current by potential cycles is attributed to the passivation due to formation of BME layer grafted to GC surface. The decrease in the peak current significantly indicates modification of GC electrode by BME. The BME oxidation peaks at $+900 \mathrm{mV}$ vs $\mathrm{Ag} / \mathrm{AgCl}(3 \mathrm{M})$ is attributed to the oxidation of the 3-hydroxyl and 3 'hydroxyl groups as reported [27].

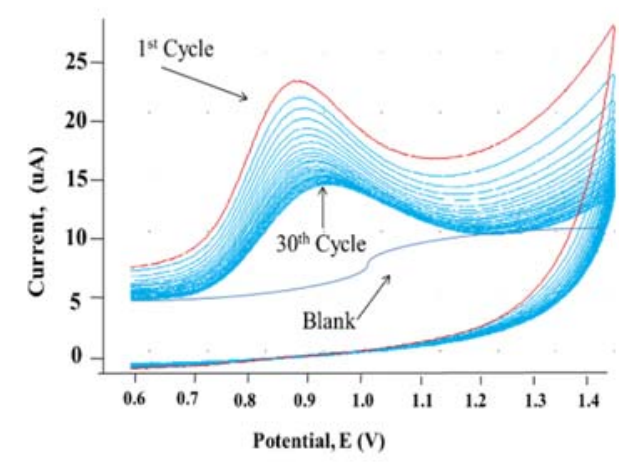

Fig. 2 Cyclic voltammograms of $0.01 \mathrm{M}$ BME in $0.04 \mathrm{M}$ BRB solution $\left(\mathrm{pH} \mathrm{7.0)}\right.$ at $30^{\text {th }}$ potential scan cycle with experimental parameters as follows: $\mathrm{E}_{\mathrm{i}}=-1200 \mathrm{mV} / \mathrm{s}, \mathrm{E}_{\mathrm{f}}=1400 \mathrm{mV} / \mathrm{s}$ vs $\mathrm{Ag} / \mathrm{AgCl}(3 \mathrm{M}), v=250 \mathrm{mV} / \mathrm{s}$. $\mathrm{Ag} / \mathrm{AgCl}(3 \mathrm{M}), v=5 \mathrm{mV} / \mathrm{s}$ and pulse amplitude, $2.5 \mathrm{mV}$.

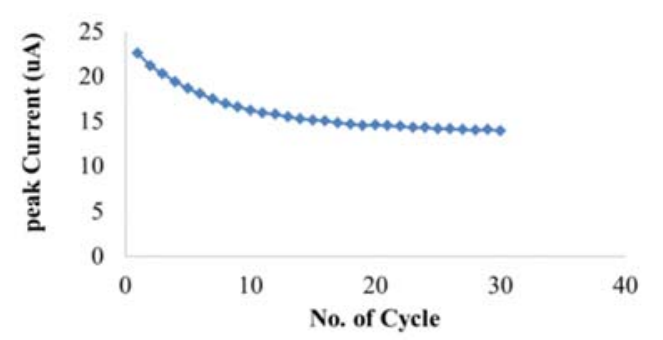

Fig 3. Plot of Ip of BME with increasing No. of cycle.

\subsection{Differential pulse anodic stripping characteristics of copper(II)-BME complexes}

Fig. 4 shows DPASV of the $\mathrm{Cu}(\mathrm{II})$ at $\mathrm{pH} 8$ in BRB as the supporting electrolyte. The stripping potentials were scanned annodically between $-0.4 \mathrm{~V}$ and $+0.3 \mathrm{~V}$ vs $\mathrm{Ag} / \mathrm{AgCl}$ (3M). The blank solution (A) which does not contains $\mathrm{Cu}$ (II) ions does not show any peak in this potential range. A small peak current (B) is observed for $\mathrm{Cu}$ (II) $0.6 \mathrm{mg} / \mathrm{mL}$ in the absence of the BME. A strong and sharp peak (C) is observed after the addition of $0.001 \mathrm{M}$ $\mathrm{BME}$ at $-0.02 \mathrm{mV}$ vs $\mathrm{Ag} / \mathrm{AgCl}(3 \mathrm{M})$ that correspond to the oxidation of $\mathrm{Cu}$ with $\mathrm{BME}$ at $\mathrm{pH}$ 6-9[7]. It was observed in the Fig. 3 that the $\mathrm{Cu}(\mathrm{II})$-BME complex is strongly adsorbed onto the GC surface electrode and 
produce a strong oxidative peak current at $-0.02 \mathrm{mV}$ vs $\mathrm{Ag} / \mathrm{AgCl}(3 \mathrm{M})$. The results therefore implies that BME has the potential to be used as the modifier for enhancement of $\mathrm{Cu}$ (II) detection by GC electrode. Table 2 shows the enhancement factor of the $\mathrm{Cu}(\mathrm{II})$ using modified $\mathrm{Cu}(\mathrm{II})$ BME electrode. It was shown that $\mathrm{pH} 8$ shows the highest percentage of enhancement with $92.93 \%$.

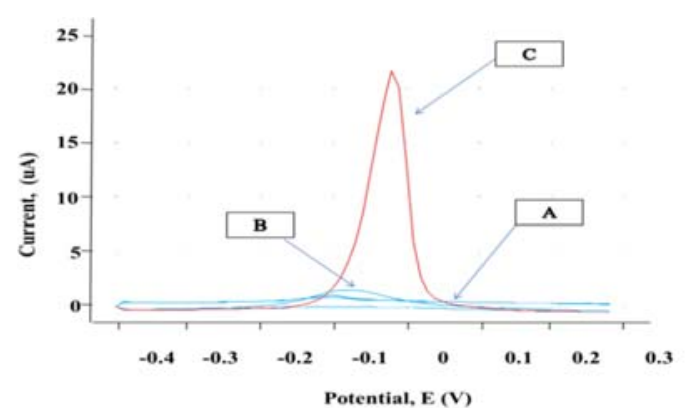

Fig. 4 Differential Pulse Anodic Stripping voltammograms of $\mathrm{Cu}$ (II)-BME in $0.04 \mathrm{M}$ BRB solution $\mathrm{pH} 8$ with experimental parameters as followed: : $\mathrm{Ei}=-400 \mathrm{mV} / \mathrm{s}, \mathrm{Ef}=300 \mathrm{mV} / \mathrm{s}$, Eacc $=-$ $1000 \mathrm{tacc}=60 \mathrm{~s}$ vs $\mathrm{Ag} / \mathrm{AgCl}(3 \mathrm{M}), \mathrm{v}=10 \mathrm{mV} / \mathrm{s}$ and rest time $2 \mathrm{~s}$. A: Blank, B: BRB + Cu(II), C: BRB + Cu(II)+ BME

Table 1 The enhancement factor of the $\mathrm{Cu}(\mathrm{II})$ using modified $\mathrm{Cu}(\mathrm{II})$-BME electrode.

\begin{tabular}{cccccc}
\hline $\mathbf{p H}$ & \multicolumn{2}{c}{$\mathbf{C u}(\mathbf{I I})-\mathbf{B M E}$} & \multicolumn{2}{c}{$\mathbf{C u}(\mathbf{I I})$} & $\begin{array}{c}\text { Enhancement } \\
(\%)\end{array}$ \\
\hline & $\begin{array}{c}\text { Current } \\
(\mathrm{uA})\end{array}$ & $\begin{array}{c}\text { Potential } \\
(\mathrm{V})\end{array}$ & $\begin{array}{c}\text { Current } \\
(\mathrm{uA})\end{array}$ & $\begin{array}{c}\text { Potential } \\
(\mathrm{V})\end{array}$ & \\
6 & 11.73 & -0.03 & 5.33 & -0.03 & 54.56 \\
7 & 12.89 & -0.04 & 3.78 & -0.07 & 70.67 \\
8 & 21.51 & -0.02 & 1.52 & -0.08 & 92.93 \\
9 & 7.29 & -0.05 & 1.25 & -0.13 & 82.85 \\
\hline
\end{tabular}

\subsubsection{Effects of $\mathrm{pH}$}

The influence of the $\mathrm{pH}$ was studied at $0.6 \mathrm{ug} / \mathrm{mL}$ $\mathrm{Cu}$ (II) ion in the $\mathrm{pH}$ range of 5-9. No peak was observed at $\mathrm{pH} 4.0$ and less while above $\mathrm{pH} 4$, there is an increase in peak currents of $\mathrm{Cu}$ (II)-BME electrode. It is clear from Fig. 5 that the potentials were found change considerably starting from $\mathrm{pH}$ 7. The increase in the $\mathrm{pH}$ gradually increased the Ip until it reached its maximum value at $\mathrm{pH}$ $8.0(21,51 \mathrm{uA}$ at Ep of $-0.02 \mathrm{~V})$. Further increase of $\mathrm{pH}$ beyond $\mathrm{pH} 8.0$, the Ip decreased until it disappeared at $\mathrm{pH}$ 10. The decrease in potentials at higher $\mathrm{pH}$ values may be due to the response of the electrode to both copper and hydroxide ions.

\subsubsection{Effect of Ligands Concentration}

The effect of BME concentration for $\mathrm{Cu}$ (II) determination was evaluated and shown in Fig 6. The use of BME as can greatly improve the sensitivity and selectivity of determinations, due to its functional sites.
The peak current intensity was increased by increasing the amount of BME and the highest peak current was obtained at at $0.003 \mathrm{M}$ of BME. However, the continuous increase of the amount of BME causes the decrease in the peak current, because excessive BME may result in a decrease in the conductivity of the electrode. So the best amount of $\mathrm{BME}$ in for Copper(II) detection is $0.003 \mathrm{M}$.

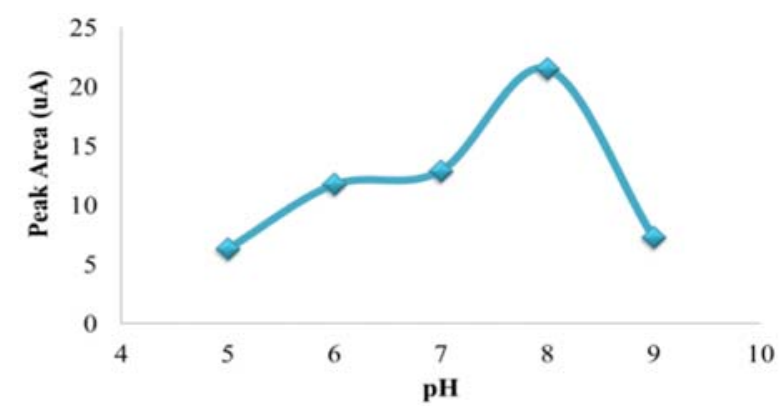

Fig. 5 Plot of peak current(uA) of $\mathrm{Cu}(\mathrm{II})-\mathrm{BME}$ in $0.04 \mathrm{M}$ BRB at different solution $(\mathrm{pH} 5,6,7,8,9)$ with experimental parameters as followed: : $\mathrm{Ei}=-400 \mathrm{mV} / \mathrm{s}, \mathrm{Ef}=300 \mathrm{mV} / \mathrm{s}, \mathrm{Eacc}=-1000 \mathrm{tacc}=60 \mathrm{~s}$ vs $\mathrm{Ag} / \mathrm{AgCl}$ (Sat'd), $v=10 \mathrm{mV} / \mathrm{s}$ and rest time $2 \mathrm{~s}$.

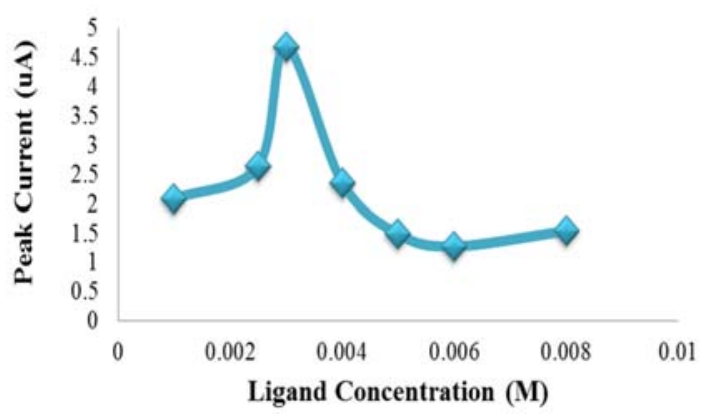

Fig. 6 Plot of peak current(uA) of $\mathrm{Cu}(\mathrm{II})-\mathrm{BME}$ in $0.04 \mathrm{M} \mathrm{BRB}$ at different BME concentration with experimental parameters as followed: : $\mathrm{Ei}=-400 \mathrm{mV} / \mathrm{s}, \mathrm{Ef}=300 \mathrm{mV} / \mathrm{s}, \mathrm{Eacc}=-1000 \mathrm{tacc}=60 \mathrm{~s}$ vs $\mathrm{Ag} / \mathrm{AgCl}$ (Sat'd), $v=10 \mathrm{mV} / \mathrm{s}$ and rest time $2 \mathrm{~s}$.

\subsubsection{Effects of accumulation time}

The variation of accumulation time between 0 and $210 \mathrm{~s}$ of $\mathrm{Cu}(\mathrm{II})-\mathrm{BME}$ were shown in Fig 7. The peak current increased gradually with the increase of accumulation time up to $200 \mathrm{sec}$ and become constant. The increase of peak current with increase of accumulation time $\left(\mathrm{t}_{\mathrm{acc}}\right)$ indicated that $\mathrm{Cu}$ (II) ions were accumulated at the surface of GC electrode. The constant peak current observe after 200 shows that the surface of the electrode has been completely saturated by the substance, so accumulation potential of $150 \mathrm{~s}$ was selected as an optimum accumulation time $\left(\mathrm{t}_{\mathrm{acc}}\right)$ for further experiment. These results showed that the limiting current of $\mathrm{Cu}$ (II) ions is controlled by the accumulation of $\mathrm{Cu}(\mathrm{II})$ at $\mathrm{GC}$ electrode. 


\subsubsection{Effect of accumulation potential}

The effects of accumulation potential was examined over the range $-0.2-0.0$ V. As illustrated in Fig. 8, the peak current increased gradually when the accumulation potential became increasingly negative up to $-0.7 \mathrm{~V}$. The results showed that the Ip slowly decreased until the Ei was $-200 \mathrm{mv}$. However at $-600 \mathrm{mV}$ the Ip sharply increased and gave a maximum response $(1.91 \mathrm{uA})$. In other words, when the Ei was changed the window of scanning potential was smaller and hence, the time for analysis became shorter. For Ei which was more negative than $-1000 \mathrm{mV}$, the scan was not performed due to the very short range of scanning potential.

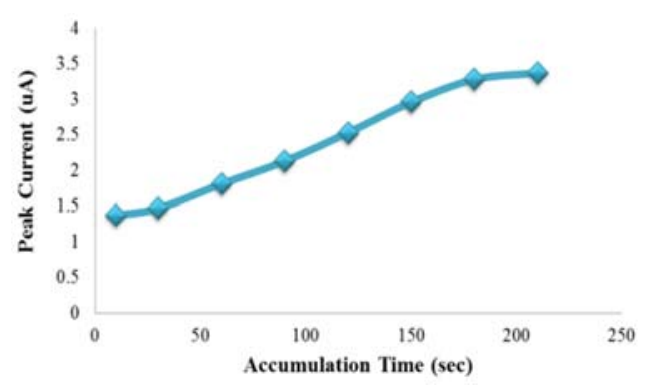

Fig. 7 Plot of peak current(uA) of $\mathrm{Cu}(\mathrm{II})-\mathrm{BME}$ in $0.04 \mathrm{M} \mathrm{BRB}$ at different accumulation time with experimental parameters as followed: : $\mathrm{Ei}=-400 \mathrm{mV} / \mathrm{s}, \mathrm{Ef}=300 \mathrm{mV} / \mathrm{s}$, Eacc $=-1000 \mathrm{tacc}=60 \mathrm{~s}$ vs $\mathrm{Ag} / \mathrm{AgCl}$ (Sat'd), $v=10 \mathrm{mV} / \mathrm{s}$ and rest time $2 \mathrm{~s}$

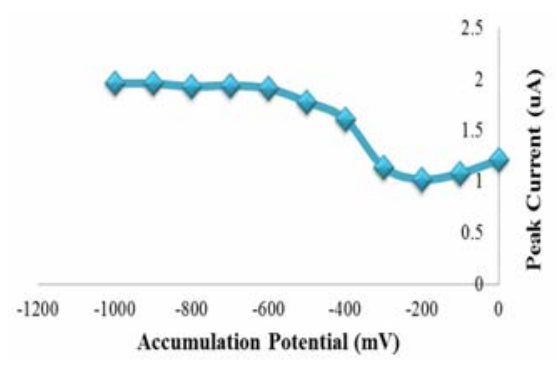

Fig. 8 Plot of peak current(uA) of $\mathrm{Cu}(\mathrm{II})-\mathrm{BME}$ in $0.04 \mathrm{M}$ BRB at different accumulation potential with experimental parameters as followed: : $\mathrm{Ei}=-400 \mathrm{mV} / \mathrm{s}, \mathrm{Ef}=300 \mathrm{mV} / \mathrm{s}$, Eacc $=-1000 \mathrm{tacc}=60 \mathrm{~s}$ vs $\mathrm{Ag} / \mathrm{AgCl}$ (Sat'd), $v=10 \mathrm{mV} / \mathrm{s}$ and rest time $2 \mathrm{~s}$.

\subsection{Limit of detection and linearity range}

The optimum parameters selected have been applied to build a calibration curve as shown in Fig 9. The calibration graph is: $\mathrm{y}=266.52 \mathrm{x}-0.1611(\mathrm{y}=$ peak current, $\mathrm{ip} / \mathrm{uA}$; $\mathrm{x}$ : the concentration of $\mathrm{Cu}(\mathrm{II}), \mathrm{Cu}(\mathrm{II}) / \mathrm{mg} / \mathrm{L})$, correlation coefficient is 0.9991 . A linear response in the 0.001-0.01 $\mathrm{mg} / \mathrm{L}$ concentration range was absorbed which was followed by decrease in sensitivity at higher concentration. A detection limit and quantification limit calculated were $0.0026 \mathrm{ugL}^{-1}$ and $0.0085 \mathrm{ugL}^{-1}$ respectively.
Repeated voltammograms under the optimal condition showed that the relative standard deviation for $0.003 \mathrm{mg} / \mathrm{L}$ and $0.007 \mathrm{mg} / \mathrm{L}$ is $0.74 \%$ and $0.86 \%$ respectively. This value is better than previously reported for other chemically modified electrode ; $5.084 \mathrm{ugL}^{-1}$ [21].

\subsection{Interference Studies}

Interference studies are very important to observe the matrix effects toward determination of Copper(II). The interference studies was conducted by spiking with excess amount of several metal ions such as Fe(II), Cd(II), Cr(II), $\mathrm{Zn}(\mathrm{II})$ and $\mathrm{Pb}(\mathrm{II})$ to the $\mathrm{BRB}$ at $\mathrm{pH} 8$ using DPASV technique under the optimum conditions. Fig 10 shows the effect of metal ions in the range 0 to $0.08 \mathrm{mg} / \mathrm{mL}$ towards Ip of $\mathrm{Cu}(\mathrm{II})-\mathrm{BME}$.
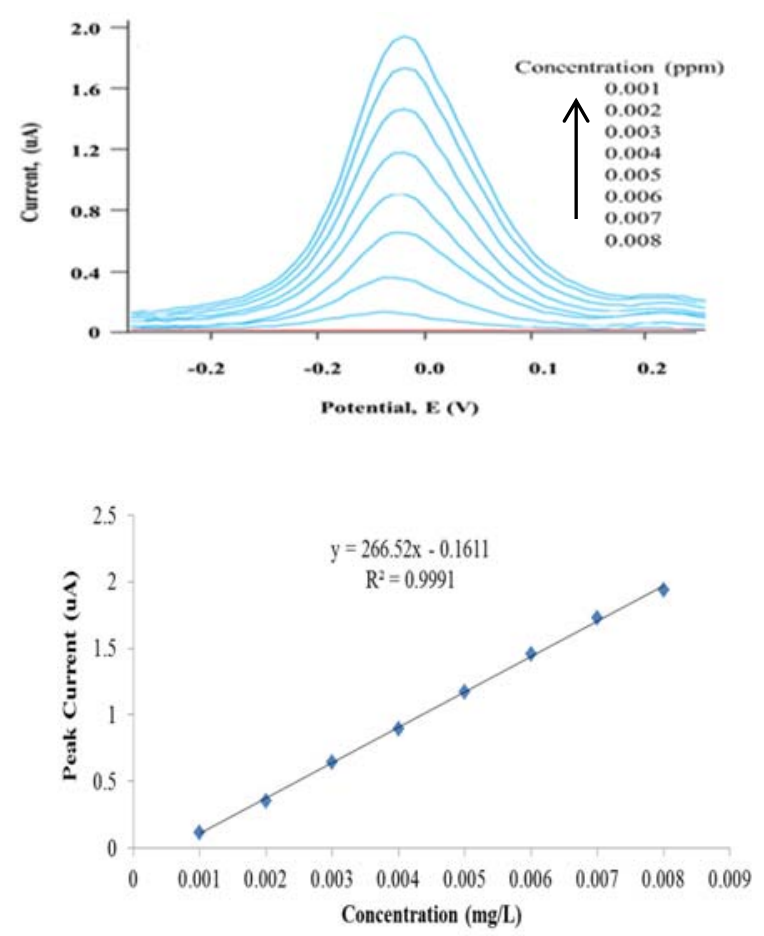

Fig. 9 Calibration curve (a) linear plot (b) and linearity range of $\mathrm{Cu}(\mathrm{II})$-BME in $0.04 \mathrm{M}$ BRB solution $\mathrm{pH} 8$ with with experimental parameters as followed: $: \mathrm{Ei}=-400 \mathrm{mV} / \mathrm{s}, \mathrm{Ef}=300$ $\mathrm{mV} / \mathrm{s}, \mathrm{Eacc}=-1000$ tacc $=180 \mathrm{~s}$ vs $\mathrm{Ag} / \mathrm{AgCl}$ (Sat'd), $\mathrm{v}=20 \mathrm{mV} / \mathrm{s}$ and rest time $12 \mathrm{~s}$.

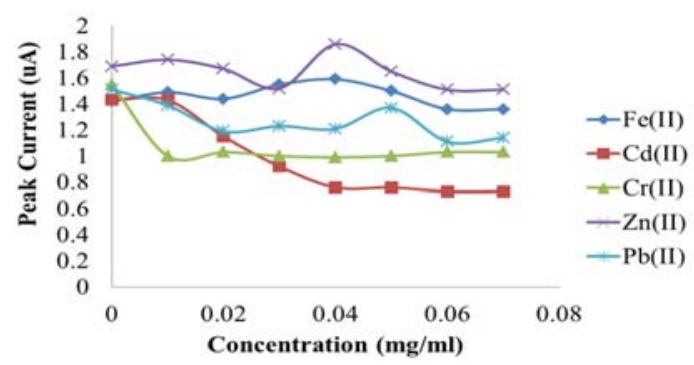

Fig. 10 The Graph of Ip of $\mathrm{Cu}(\mathrm{II})$-BME with increasing concentration of $\mathrm{Fe}(\mathrm{II}), \mathrm{Cd}(\mathrm{II}), \mathrm{Cr}(\mathrm{II}), \mathrm{Zn}(\mathrm{II})$ and $\mathrm{Pb}(\mathrm{II})$ ion in BRB solution $\mathrm{pH} 8$. 


\subsection{Application to real sample}

The developed method was tested by determine $\mathrm{Cu}(\mathrm{II})$ in tap water. Each sample was filtered using filter paper. The analysis was performed by standard addition method to eliminate the matrix effects. The amount added were $0.003 \mathrm{mg} / \mathrm{mL}$ and the result obtained were $0.0031 \pm$ $0.03 \mathrm{mg} / \mathrm{mL}$ with recoveries of $96.55 \%$. There were no significant different between the found and the added concentrations indicating the $\mathrm{Cu}(\mathrm{II})$-BME electrode can be successfully used for the determination on $\mathrm{Cu}$ (II) in natural samples under the optimized conditions and using the standard addition approach.

\section{CONCLUSION}

A highly sensitive, rapid, simple and selective stripping method on a GC electrode has been developed and enhanced for the determination of trace copper(II) by using the newly synthesized Schiff base N,N'-bis(2hydroxy-4-methoxyacetophenone)ethylenediamine (BME). This method was successfully applied to determination of $\mathrm{Cu}(\mathrm{II})$ in real sample which is tap water.

\section{ACKNOWLEDGEMENT}

The authors thank the Department of Chemistry, Faculty of Science Universiti Teknologi Malaysia, Johor for NMR facilities as well as to Malaysian Government (FRGS) vot 4F186 for funding the project.

\section{REFERENCES}

[1] T.W. Lin, S.D. Huang, Anal. Chem. 73 (2001) 4319

[2] D.L. Watts, J. Orthomol. Med. 4 (1989) 99.

[3] N.G. Beck, R.P. Franks, K.W. Bruland, Anal. Chim. Acta. 455 (2002) 11.
[4] M.A. Mesquita Da Silva, V.L. Azzolin Frescura, A.J. Curtius, Spectrochim. Acta. B. 55 (2000) 803.

[5] T. Alemdaroğlu, E. Onur, H. Akgün, Int. J. of Environ Stud. 57 (2000) 157.

[6] M. Sheibani, F. Marahel, M. Montazerozohori, Toxicol. Environ. Chem. 93 (2011) 860.

[7] M. Rajabi, A. Asghari, H.Z. Mousavi, J. Anal. Chem. 65 (2010) 511.

[8] S. Chaiyo, O. Chailapakul, T. Sakai, N. Teshima, W. Siangproh, Talanta. 108 (2013) 1.

[9] W.W. Zhu, N.B. Li, H.Q. Luo, Talanta. 72 (2007) 1733.

[10] J.M. Trindade, L.C. Martiniano, V.R.A. Gonalves, A.G. Souza, A.L.B. Marques, G.L. Baugis, T.C.O. Fonseca, C. Song, J. Zhang, E.P. Marques, Fuel. 91 (2012) 26.

[11] A.H. Alghamdi, A.F. Alghamdi, M.A. Alomar, Portugaliae Electrochim Acta. 27 (2009) 645.

[12] S. Abbasi, A. Bahiraei, F. Abbasai, Food. Chem. 129 (2011) 1274.

[13] A.A. Ensafi, T. Khayamian, S.S. Khaloo, Anal. Chim Acta. 505 (2004) 201.

[14] J. Jakmunee, J. Junsomboon, Talanta. 77 (2008) 172.

[15] A.A. Ensafi, M.A. Naeeni, Anal Lett. 33 (2000) 1591.

[16] S. Abbasi, H. Khani, R. Tabaraki, Food Chem. 123 (2010) 507.

[17] M. Behpour, S.M. Ghoreishi, N. Mohammadi, N. Soltani, M. Salavati-Niasari, Corros. Sci. 52 (2010) p. 4046-4057.

[18] A.M. Rashvand, M. Jafarian, S. Etezadi, F. Gobal, M. Khakali, S. Rayati, M.M. Ghasem, Talanta. 108 (2013) 19.

[19] S. Vijayalakshmi, S. Kalyanaraman, Opt Mater. 35 (2013) 440.

[20] A. Prakash, D. Adhikari, International Journal of ChemTech Research. 3 (2011) 1891.

[21] I. Cesarino, É.T.G. Cavalheiro, C.M.A. Brett, Electroanal. 22 (2010) 61 .

[22] A. Afkhami, H. Bagheri, H. Khoshsafar, M. Saber-Tehrani, M. Tabatabaee, A. Shirzadmehr, Anal Chim Acta. 746 (2012) 98.

[23] S. Shahrokhian, Z. Kamalzadeh, A. Bezaatpour, D.M. Boghaei, Sensor Actuat B-Chem. 133 (2008) p. 599-606.

[24] S. Sadeghi, M. Eslahi, M.A. Naseri, H. Naeimi, H. Sharghi, A. Shameli, Electroanalysis. 15 (2003) 1327.

[25] H.A. Arida, J.P. Kloock, M.J. Schöning, Sensors. 6 (2006) 435

[26] V.K. Gupta, A.K. Jain, G. Maheshwari, Talanta. 72 (2007) 49.

[27] Y. Oztekin, A. Ramanaviviene, N. Ryskevic, Z. Yazicigil, Z. Ustanda, A.O. Solak, A. Rmanavicius, Sensor Actuat B-Chem. 157 (2011) 146. 